\title{
Molecular Cytogenetics in metaphase and interphase cells for diagnosis and prognosis in cancer and genetic research*
}

\author{
María Mühlmann-Díaz
} Comisión Nacional de Energía Atómica (CNEA); Consejo Nacional de Ciencia y Tecnología (CONICET),
Buenos Aires, Argentina. E-mail: muhlmann@cnea.gov.ar

\begin{abstract}
*Presented at the International Graduate School Course and Workshop on "New Approaches in the Study of Radiation-Induced and Cancer-Associated Chromosomal Aberrations"
\end{abstract}

\section{INTRODUCTION}

The development of Molecular Cytogenetics has increased considerably since Pinkel et al. (1986) described for the first time the fluorescence in situ hybridization (FISH) technique. FISH allows the identification of specific sequences in a structurally preserved cell, either in metaphase or interphase (Poddighe et al., 1991).

The technique, based on the complementary doublestranded nature of DNA, consists in the hybridization of labeled specific DNA fragments (probe) on chromosome spreads or tissue sections. The probe can be labeled with a reporter molecule which is detected using fluorochromeconjugated antibodies. Since it is extremely difficult to obtain mitotic cells from some specimens, it is also possible to apply FISH techniques to interphase cells.

Although FISH is still used principally in research (Cornforth et al., 1989; Mühlmann-Díaz and Bedford, 1993, 1994; Gray et al., 1994; Geard and Jenkins, 1995), diagnostic applications are increasing steadily (Klinger et al., 1992; Beverloo et al., 1995; Tucker et al., 1995). New diagnostic applications are being added to the current extended research use; particularly, aneuploidies and malignancies which are easily detected by FISH.

Due to the fact that, chromosomal abnormalities in tumors are difficult to classify, the technique of comparative genomic hybridization (CGH), a competitive FISH, allows one to determine complete and partial chromosome gains and losses (Kallioniemi et al., 1992; duManoir et al., 1993). CGH results will thus allow the classification of many tumor cell lines and together with other complementary techniques such as microdissection-FISH and primed in situ hybridization will increase the possibility to select appropriate treatment for cancer patients.

When the improvements in cytogenetic techniques seemed to have reached a plateau, a combination of cytogenetics and molecular biology gave rise to FISH, opening considerable new research opportunities in the field.
The main reasons for this were:

1 - It opened the possibility of obtaining cytogenetic results on interphase cells. This was not possible to achieve prior to FISH techniques;

2 - The color images obtained are easy to analyze;

3 - Since DNA is a very stable molecule, it is possible to study archived material and paraffin-embedded tissues;

4 - It can also be combined with other cytogenetic and molecular techniques, improving the results obtained.

FISH techniques are extensively used in many fields, such as radiation biology, somatic cell genetics, prenatal and postnatal diagnosis, as well as preimplantational studies. However, other fields like microbiology, ecology and evolution are still relatively unexplored. The development of probes for animal research models and for specific diagnosis in species of agricultural and animal economic importance will provide many new applications of molecular cytogenetics.

\section{BRIEF DESCRIPTION OF APPLICATIONS}

\section{Radiation-biology}

In this field, radiation effects on living organisms and how different conditions and parameters can modify the final outcome are studied. The purpose of these studies is to be able to predict and prevent radiation damage, optimizing radiation usage and maximizing benefits for human beings and the environment.

FISH has been one of the latest methodologies used in the field of radiation biology, bringing many new insights into the study of mechanism of aberration production including initial chromosome damage and the repair systems involved (Cornforth et al., 1989; Mühlmann-Díaz and Bedford, 1993, 1994, 1998; Folle et al., 1998), radiobiodosimetry (Edwards, 1997; Tucker et al., 1997) and predictive assays (Coco-Martin et al., 1994).

Radiation-induced aberrations is one of the param- 
eters analyzed after nuclear accidents. In this way, it is possible to estimate the risk that the victims will have to confront and to take preventive measures accordingly. Chromosomal aberrations produced by radiation can be symmetrical or asymmetrical. The asymmetrical type aberrations (those which have an acentric fragment such as dicentrics, interstitial deletions and asymmetrical exchanges) are lethal for the cells. Acentric fragments cannot attach to the spindle in mitosis and are usually lost, so cells carrying them will lack genetic information and will be eliminated from the cell population after a few post-irradiation generations. On the other hand, symmetrical type aberrations also decrease in the generations following irradiation, but since they do not carry an acentric fragment, they can survive as a clone in bone marrow, allowing their detection many years after radiation exposure (Lucas $e t$ al., 1992).

In cases of whole body irradiation, the exposure can be estimated through the analysis of the aberration frequency. The chromosomal aberration frequency obtained using probes for just a few chromosomes can be extrapolated in order to determine whole chromosome frequency of exchanges (Gebhart et al., 1996).

Radiation is also used for medical purposes and it is not uncommon to find patients who overreact to standard protocols. On the other hand, some tumors are highly resistant to radiation therapy. The frequency of chromosomal aberrations after tumor irradiation in vivo has been reported as a tool to distinguish tumor sensitivity or resistance to radiation. A noninvasive technique, which means aberration scoring on peripheral blood, is being developed in order to try to detect possible overreactions in patients that need radiotherapy. The same system is used to detect cancerprone patients. For these studies, aberration scoring with solid Giemsa staining does not seem to have enough sensitivity. Some researchers are trying to adjust this method with FISH painting, which has already been used in tumor cells (Coco-Martin et al., 1994).

\section{Somatic cell genetics}

Genetics of somatic cells allow us to study features related to chromosome topology, nuclear structure and gene mapping (Sachs et al., 1993) as well as different malignancies and abnormalities related to cancer in hematological alterations and solid tumors (Siebert and Weber-Matthiesen, 1997).

Chromosomal aberrations are found in cancer and tumor cell lines. Some of them were already characterized and correlated with specific syndromes (Tables I and II)

Table I - Hematological cancers.

\begin{tabular}{|c|c|c|}
\hline Pathology & Detectable anomaly & Application \\
\hline $\begin{array}{l}\text { Chronic myelogenous leukemia } \\
\text { Acute myeloid leukemia }\end{array}$ & $\begin{array}{l}\text { Translocation } 9 ; 22 \\
\text { BCR/ABL genes } \\
\text { Trisomy } 8 \\
\text { Trisomy } 19 \\
\text { Trisomy } 21 \\
\text { Iso (17q) }\end{array}$ & $\begin{array}{l}\text { Diagnosis } \\
\text { Prognosis }\end{array}$ \\
\hline $\begin{array}{l}\text { Chronic myelogenous leukemia } \\
\text { Acute lymphocytic leukemia } \\
\text { Myeloproliferative disorders } \\
\text { Myelodysplastic syndromes } \\
\text { Chronic lymphocytic leukemia } \\
\text { Polycythemia vera }\end{array}$ & $\begin{array}{l}\text { Trisomy } 8 \\
8(\mathrm{p} 11.1-\mathrm{q} 11.1)\end{array}$ & $\begin{array}{l}\text { Prognosis } \\
\text { Myeloid blast crisis and } \\
\text { basophilia }\end{array}$ \\
\hline $\begin{array}{l}\text { Acute lymphocytic leukemia } \\
\text { Therapy-related chronic myelogenous } \\
\text { Leukemia } \\
\text { Myelodysplastic syndromes }\end{array}$ & $\begin{array}{l}\text { Deletion 5q31 } \\
\text { ERG-1 }\end{array}$ & Prognosis \\
\hline Acute promyelogenous leukemia (APL) & $\begin{array}{l}\text { Translocation 15;17 } \\
\text { PML/RARA } \\
\text { 3'RAR/5'RARA }\end{array}$ & $\begin{array}{l}\text { Diagnosis } \\
\text { Prognosis } \\
\text { Early chemotherapy in } \\
\text { APL is critical. }\end{array}$ \\
\hline Myelodysplastic syndromes & $\begin{array}{l}\text { 7q31 } \\
\text { D 75486 }\end{array}$ & Follow-up \\
\hline B-cells chronic lymphocytic leukemia & $\begin{array}{l}\text { Deletion 13q } \\
\text { D13525 13q14.3 } \\
\text { P53Deletion 17p13.1 }\end{array}$ & $\begin{array}{l}\text { Prognosis } \\
\text { Therapy resistance }\end{array}$ \\
\hline $\begin{array}{l}\text { Childhood B cell } \\
\text { Acute lymphocytic leukemia }\end{array}$ & $\begin{array}{l}\text { Translocation 12;21 } \\
\text { TEL/AML1 }\end{array}$ & $\begin{array}{l}\text { Prognosis } \\
\text { MRD checking }\end{array}$ \\
\hline $\begin{array}{l}\text { Chronic lymphocytic leukemia } \\
\text { Acute lymphoblastic leukemia } \\
\text { Follow-up in bone marrow transplant } \\
\text { Minimal residual disease (MRD) }\end{array}$ & $\begin{array}{l}\text { Trisomy 12p11-q11 } \\
\text { Isochromosome } 17 \\
\text { 17q11-q12 }\end{array}$ & $\begin{array}{l}\text { Prognosis } \\
\text { Myeloid blast crisis and } \\
\text { Basophilia }\end{array}$ \\
\hline
\end{tabular}


Table II - Solid tumors

\begin{tabular}{|c|c|c|}
\hline Pathology & Detectable anomaly & Application \\
\hline Retinoblastoma & $\begin{array}{l}\text { RB1 gene: 13q14 } \\
\text { D13525 }\end{array}$ & Diagnosis \\
\hline Breast cancer & $\begin{array}{l}\text { Deletion 7q31-D75522 } \\
\text { Amplification 17q11.2q12 } \\
\text { Her-2/neu } \\
\text { Amplification 8q24.2-q24.3 } \\
\text { Oncogene c-Myc } \\
\text { Amplification 20q13.2 } \\
\text { Amplification } \\
11 \mathrm{q} 13\end{array}$ & $\begin{array}{l}\text { Prognosis } \\
\text { Therapy } \\
\text { resistance }\end{array}$ \\
\hline Neuroblastoma & $\begin{array}{l}\text { Amplification N-myc } \\
\text { 2p23-p24 }\end{array}$ & $\begin{array}{l}\text { Prognosis } \\
\text { Evolution }\end{array}$ \\
\hline Colon carcinoma & Deletion 13q14 & $\begin{array}{l}\text { Diagnostic } \\
\text { prognostic }\end{array}$ \\
\hline Osteosarcoma & RB-1 & $\begin{array}{l}\text { Treatment } \\
\text { indicator }\end{array}$ \\
\hline \multirow[t]{2}{*}{$\begin{array}{l}\text { Recurrent pros- } \\
\text { tate tumors }\end{array}$} & Amplification Xq12 & $\begin{array}{l}\text { Diagnosis- } \\
\text { Prognosis }\end{array}$ \\
\hline & Androgen receptor locus & $\begin{array}{l}\text { Treatment } \\
\text { indicator }\end{array}$ \\
\hline
\end{tabular}

and some have yet to be characterized with a clinical outcome. The continuous input of information and reports connecting clinical and biochemical data with chromosomal and genetic data will increase the list of known genes involved in each malignancy. The great advantage of molecular cytogenetic techniques in these cases is the possibility to study interphase cells. A good example is the amplification of the Her/2 neu oncogene. About $30 \%$ of breast tumors (and other tumors) exhibit amplification of this oncogene. These tumors have a bad prognosis, because they usually do not respond to the regular chemotherapeutic protocol and are very aggressive in the patient. The oncogene encodes for a membrane growth factor receptor. A humanized antibody against the specific receptor, which improves the condition of these patients considerably, has recently been approved by the FDA. This is a typical example of how we can employ interphase cytogenetics on archived paraffin-embedded tissues.

Chromosome trisomy involving chromosome 12 is a common feature of some leukemias (Cuneo et al., 1997). FISH with centromere probes allows us to count enough cells to carry out statistical scoring in interphase cells, making the study of minimal residual disease much faster and less demanding that the study of metaphase cells by classical karyotyping.

\section{Advanced molecular cytogenetics applied to neoplasias}

Interphase cytogenetics is indeed very useful when we know what we are looking for. However, genetically unstable solid tumors pose a different problem. After the initial mutation some tumors become unstable and soon exhibit a wide range of different chromosomal aberrations. In these cases, CGH becomes a very useful tool.

$\mathrm{CGH}$ is based on a competition between normal cell DNA and a tumor test DNA that allows us to detect deletions or amplifications pertaining to the whole tumor cell population. Although CGH is not able to detect balanced translocations, it is a very useful tool because it allows one to recognize unbalanced aberrations, a common feature of the whole tumor (Hermsen et al., 1996).

Homogeneously stained regions (HSR) and double minutes (DM) are forms of DNA amplification that appear in some types of malignancies. Microdissection of chromosomes and subsequent probe development (Xu et al., 1996) allows us to map the origin of HSR or DM. By developing a probe from those microdissected regions we can use a normal cell as a target and determine from which chromosome region the amplified DNA comes from.

\section{Hereditary genetics}

Includes syndromes that can be transmitted or that develop spontaneously during conception or embryogenesis.

\section{Prenatal testing}

The fact that FISH allows us to perform interphase cytogenetics makes it suitable for rapid prenatal diagnosis. Specific probes can be used for the most common alterations, providing a fast result while standard cytogenetic studies are still in process. Furthermore, the probability of detecting mosaicisms increases since both metaphases and interphases are included in the scoring (Perandones et al., 1998).

\section{Postnatal, microdeletion syndromes}

As mentioned before, there is no methodology available that can resolve all cases. Some syndromes and mutated specific loci can be detected or diagnosed by PCR, but in cases where a microdeletion is involved, PCR is not useful since quantitative PCR is more complicated. Specific locus FISH probes can answer this problem. In these cases, we have one chromosome in which one locus is deleted and the other is normal. Classical cytogenetics cannot detect these deletions because they correspond to microdeletions of a few hundred base pairs (Table III).

\section{Preimplantational genetics}

Some phenotypically normal persons can carry balanced translocations or other types of chromosomal aberrations. It is usually difficult for them to have offspring, or if they do often their children have serious health problems. In other cases, the abnormalities are spontaneous but parents 
Table III - Microdeletion syndromes.

\begin{tabular}{|ll|}
\hline Syndrome & Locus \\
\hline Prader Willi/Angelman & 15q11-q13//15p11.2// \\
Williams syndrome (elastin gene) & 15q22 SNRPN and D15S10 \\
Kallman's region & Xp22.3 KAL \\
Cri-du-Chat & D5S23 5p15.2 \\
Steroid sulfatase & Xp22.3 STS \\
Smith-Magenis & $17 \mathrm{q} 11.2$ \\
Miller-Dieker & $17 \mathrm{p} 12.3$ \\
Wolf-Hirschhorn & $4 \mathrm{p} 16.3$ \\
\hline
\end{tabular}

are afraid to repeat a bad experience and they ask for prenatal testing. In any case, the long wait necessary with conventional cytogenetics causes a lot of anxiety that could be minimized by means of molecular cytogenetic techniques.

As FISH can be performed in a single cell, preimplantation diagnosis is possible. Knowing a priori what we are looking for, a combination of centromere probes can be used to detect aneuploidies (Coonen et al., 1998). When the female carries the translocation, pre-ICSI determination of the quality of the oocyte can be ascertained by analysis of the polar bodies (Verlinsky et al., 1998). If the male carries the translocation, studies on the disjunction of the sperm can determine the probability that a single sperm is normal.

Other less developed applications of FISH but with a promising future are:

\section{Microbiology}

This area is perhaps the least developed, but further illustrates the multiple uses of FISH (Pillai, 1997). Diagnoses of the presence of certain viruses have been made using probes for specific DNA of the studied agent.

$$
\text { Ecology }
$$

Chromosomal aberrations are an endpoint for genetic damage. Radiation by itself or potentiated by other contaminants can cause slight genetic damage (Ulsh et al., 2000) and this might not be phenotypically expressed. However, a translocation may decrease the pregnancy rate and this, in turn, could slowly decrease the population growth of some species in the contaminated area. People living in the surrounding areas might also be involved and the induced damage could not only affect their lives in the long run but also in future generations.

\section{Evolution}

During the evolutionary process, some chromosome structures are conserved while others are involved in interchanges. FISH can show that related species not only have common genes but also share chromosome regions (Wienberg and Stanyon, 1997).
Agricultural and farm animal economy

Chromosomal aberrations were first analyzed only by banding techniques. Classical cytogenetics is based on species-specific bands in order to determine the chromosomal exchanges that lead to aberrations. The training to analyze banding patterns is indeed hard since every species has its own banding pattern that the technician should interpret precisely. Moreover, in many species banding techniques do not work properly. This aspect, added to the fact that there is not always sufficient information in the literature, makes it difficult to make a correct classification of chromosomes.

\section{PAST, PRESENT AND FUTURE}

Once a specific labeled DNA probe is available, FISH becomes the technique of choice. That is the reason why FISH has been so useful in different fields (Nkongolo $e t$ al., 1993; Goldammer et al., 1999).

Molecular cytogenetics has gone a long way in a short time. Efficiency and sensitivity have improved by combining methodologies. The FDA has already approved some of diagnostic tests and more are under study for their approval. However, many probes still need to be developed for specific human genes and chromosome fragments as well as for nonhuman species.

\section{REFERENCES}

Beverloo, H.B., Le Coniat, M., Wijsman, J., Lillington, D.M., Bernard, O., de Klein, A., van Wering, E., Welborn, J., Young, B.D. and Hagemeijer, A. (1995). Breakpoint heterogeneity in t(10;11) translocation in AML-M4/M5 resulting in fusion of AF10 and MLL is resolved by fluorescent in situ hybridization analysis. Cancer Res. 55: 42204224.

Coco-Martin,J.M., Smeets, M.F.M.A., Poggensee, M., Mooren, E., Hofland, I., van den Brug, M.C., Ottenheim, H., Bartelink, A.C. and Begg, A.C. (1994). Use of fluorescence in situ hybridization to measure chromosome aberrations as a predictor of radiosensitivity in human tumour cells. Int. J. Radiat. Biol. 66: 297-307.

Coonen, E., Hopman, A.H., Geraedts, J.P. and Ramaekers, F.C. (1998). Application of in situ hybridization techniques to study human preimplantation embryos: a review. Hum. Reprod. Update 4: 135-152.

Cornforth, M.N., Meyne, J., Littlefield, L.G., Bailey, S.M. and Moyzis, R.K. (1989). Telomere staining of human chromosomes and the mechanism of radiation-induced dicentric formation. Radiat. Res. 120: 205212.

Cuneo, A., Bigoni, R., Roberti, M.G., Bardi, A., Balsamo, R., Piva, N. and Castoldi, G. (1997). Detection of numerical aberrations in hematologic neoplasias by fluorescence in situ hybridization. Haematologica 82: 85-90.

duManoir, S., Speicher, M.R., Joos, S., Schroeck, E., Popp, S., Doehner, H., Kovacs, G., Robert-Nicoud, M., Lichter, P. and Cremer, T. (1993). Detection of complete and partial chromosome gains and losses by comparative genomic in situ hybridization. Hum. Genet. 90: 590-610.

Edwards, A.A. (1997). The use of chromosomal aberrations in human lymphocytes for biological dosimetry. Radiat. Res. 148: S39-S44.

Folle, G.A., Martínez-López, W., Boccardo, E. and Obe, G. (1998). Localization of chromosome breakpoints: implication of the chromatin structure and nuclear architecture. Mutat. Res. 404: 17-26.

Geard, C.R. and Jenkins, G. (1995). Human chromosome-specific changes in a human-hamster hybrid cell line (AL) assessed by fluorescent in 
situ hybridization (FISH). Int. J. Rad. Oncol. Biol. Phys. 32: 113-120.

Gebhart, E., Neubauer, S., Schmitt, G., Birkenhake, S. and Dunst, J. (1996). Use of a three-color chromosome in situ suppression technique for the detection of past radiation exposure. Radiat. Res. 145: 47-52.

Goldammer, T., Brunner, R.M., Kang'a, S., Hanotte, O. and Schwerin, M. (1999). Establishment of bovine chromosome region specific high resolution maps using microdissection. Anim. Biotechnol. 10: 113118.

Gray, J., Pinkel, D. and Brown, M. (1994). Review. Fluorescence in situ hybridization in cancer and radiation biology. Radiat. Res. 137: 275 289.

Hermsen, M.A., Meijer, G.A., Baak, J.P., Joenje, H. and Walboomers, J.J. (1996). Comparative genomic hybridization: A new tool in cancer pathology. Hum. Pathol. 27: 342-349.

Kallioniemi, A., Kallioniemi, O.-P., Sudar, D., Rudovitz, D., Gray, J.W. Waldman, F.M. and Pinkel, D. (1992). Comparative genomic hybridization for molecular cytogenetic analysis in solid tumors. Science 258: 818-821

Klinger, K., Landes, G., Shook, D., Harvey, R., Lopez, L., Locke, P., Lerner T., Osathanondh, R., Leverone, B. and Houseal, T. (1992). Rapid detection of chromosome aneuploidies in uncultured amniocytes by using fluorescence in situ hybridization (FISH). Am. J. Hum. Genet. 51: 55-65.

Lucas, J.N., Awa, A., Straume, T., Poggensee, M., Kodama, Y., Nakano, M., Ohtaki, K., Weier, H.-U., Pinkel, D., Gray, J. and Littlefield, G. (1992). Rapid translocation frequency analysis in human decades after exposure to ionizing radiation. Int. J. Radiat. Biol. 62: 53-63.

Martínez-López, W., Boccardo, E., Folle, G.A., Porro, V. and Obe, G. (1998) Intrachromosomal localization of aberration breakpoints induced by neutron and gamma rays in Chinese hamster ovary cells. Radiat. Res. 150: 585-592.

Mühlmann-Díaz, M.C. and Bedford, J.S. (1993). Breakage of human chromosomes 4, 19 and Y in G0 cells immediately after exposure to gammarays. Int. J. Rad. Biol. 65: 165-173.

Mühlmann-Díaz, M.C. and Bedford, J.S. (1994). A comparison of radiation-induced aberrations in human cells involving early and late replicating X chromosomes. In: Chromosomal Alterations: Origin and Significance (Obe, G. and Natarajan, A.T., eds.). Springer-Verlag, Berlin, pp. 125-131.

Nkongolo, K.K., Lapitan, N.L.V., Quick, J.S. and Mühlmann, M.C. (1993). An optimized fluorescence in situ hybridization procedure for detecting rye chromosomes in wheat. Genome 36: 701-705.

Perandones, C., Cerretini, R., Bozzo, W., Banares, V., Alba, L., Sala, A., Pivetta, O., Corach, D. and Mühlmann-Diaz, M.C. (1998). Diploid- triploid mosaicism in chorionic villus sampling (CVS): Clinical significance and prenatal assessment. Bio-Medicina 10: 425-429.

Pillai, S.D. (1997). Rapid molecular detection of microbial pathogens: breakthroughs and challenges. Arch. Virol. (Suppl.) 13: 67-82.

Pinkel, D., Straume, T. and Gray, J.W. (1986). Cytogenetic analysis using quantitative, high-sensitivity, fluorescence hybridization. Proc. Natl. Acad. Sci. USA 83: 2934-2938.

Poddighe, P.J., Moesker, O., Smeets, D., Awwad, B., Ramaekers, C. and Hopman, A. (1991). Interphase cytogenetics of haematological cancer: Comparison of classical karyotyping and in situ hybridization using a panel of eleven chromosome specific DNA probes. Cancer Res. 51: 1959-1967.

Sachs, R.K., Awa, A., Kodama, Y., Nakano, M., Ohtaki, K. and Lucas, J.N. (1993). Ratios of radiation-produced chromosome aberrations as indicators of large-scale DNA geometry during interphase. Radiat. Res. 133: 345-350.

Siebert, R. and Weber-Matthiesen, K. (1997). Fluorescence in situ hybridization as a diagnostic tool in malignant lymphomas. Histochem. Cell Biol. 108: 391-402.

Tucker, J.D., Morgan, W.F., Awa, A.A., Bauchinger, M., Blakey, D., Cornforth, M.N., Littlefield, L.G., Natarajan, A.T. and Shasserre, C. (1995). A proposed system for scoring structural aberrations detected by chromosome painting. Cytogenet. Cell. Genet. 68: 211-221.

Tucker, J.D., Tawn, E.J., Holdsworth, D., Morris, S., Langlois, R., Ramsey, M., Kato, P., Boice Jr., J., Tarone, R. and Jensen, R. (1997). Biological dosimetry of radiation workers at the Sellafield nuclear facility. Radiat. Res. 148: 216-226.

Ulsh, B.A., Mühlmann-Diaz, M.C., Whicker, F.W., Congdon, J.D., Hinton, T.G. and Bedford, J.S. (2000). Chromosome translocations in turtles: A biomarker in a sentinel animal for ecodosimetry. Radiat. Res. (in press).

Verlinsky, Y., Cieslak, J., Ivakhnenko, V., Evsikov, S., Wolf, G., White, M., Lifchez, A., Kaplan, B., Moise, J., Valle, J., Ginsberg, N., Strom, C. and Kuliev, A. (1998). Preimplantation diagnosis of common aneuploidies by the first- and second-polar body FISH analysis. J. Assist. Reprod. Genet. 15: 285-289.

Wienberg, J. and Stanyon, R. (1997). Comparative painting of mammalian chromosomes. Genet. Develop. 7: 784-791.

Xu, J., Tyan, T., Cedrone, E., Savaraj, N. and Wang, N. (1996). Detection of 11 q13 amplification as the origin of a homogeneously staining region in small cell lung cancer by chromosome microdissection. Genes Chromosomes Cancer 17: 172-178.

(Received November 23, 2000) 
